\title{
Gusty winds may exist
}

The above phrase appears on a roadside sign near one of the more exposed highways in the canyons of Northern New Mexico. The curiously existential quality of the wording always makes me think, as we ride past it, 'Gusty winds DO exist, but not HERE, not just NOW.'

The seemingly endless presidential campaign in the US is blowing both hot and cold winds and they are picking up speed. One of the few positive effects of the past 7 years of national embarrassment is that both parties realise that ignoring health care in the country is impossible. The announcement in January 2008 that the 2006 medical bill in the US was more than $\$ 2$ trillion had a sobering effect on even the most exuberant advocates of the medical marketplace.

No one believes the current system is sustainable. Healthcare costs continue to rise at almost three times the rate of inflation. Any 'decrease' in the past two decades is, in reality, 'a decrease in the rate of increase'. Distress over healthcare costs have been spreading to the uppermiddle class whose costs are growing. As one of my patients, whose insurance deductible is $20 \%$, said about her recent hospitalisation, ' $20 \%$ of $\$ 25$ thousand is a lot of money'. The number of uninsured continues to grow relentlessly.

As if I needed reminding, on a recent trip to Cleveland my naturalised SudaneseAmerican taxi driver pointed out that he drives people who fly from around the world to go to the famous medical centres in the city through neighbourhoods where most people do not have any health care at all. As 'Kenny' said, 'why are we not embarrassed at this?' Why not indeed.

The traditional Republican talk about a fiscally responsible government has been summarily trashed by President Bush who has used a war to spend the country into an economic recession that continues to spread. Cost containment seems to have come a bit late into the discussion. Some Republican governors have actually tried to extend care to citizens in their states but are backing and filling as the election heats up because universal coverage is seen by Republican fundamentalists as vaguely socialist. Republicans also seem to be saying that immigrants, who pay taxes, raise families and have two jobs to stay ahead, might suddenly become lazy if we brought them into any universal health scheme. It would sap their moral fibre.

Democrats all use universal health care as a focus of their plans, pretending to ignore the hospital associations, big pharma and insurance companies that are lining up to donate to the Democratic party in the hope of getting the best deal they can from whoever is the nominee and, presumptively, the favourite to be the next president. Even if they believed their own rhetoric about universal coverage, the two remaining Democratic candidates are very short on experience, since both of them are senators who talk theory rather than reality, having never faced a balanced budget or fiscal restraint. Senator Clinton failed miserably in one of the only opportunities we had since the 1940s at broad health-system reform.

Americans always equate health care with 'insurance.' Insurance companies make us believe that we should be able to understand how they work but, somehow, we can't. They make the average person feel like the claimant in the Monty Python Insurance Sketch who has, unfortunately, opted for the 'Neverpay' policy. My father sold insurance for 40 years, yet he would always ask me to explain his medical bills. Even when the paper said 'This is not a bill,' he wouldn't believe it. 'If this is not a bill, why are they sending it to me?' he would ask. The candidates from both parties rarely talk about 'health insurance' but rather 'health care', hoping that the public forgets that insurance companies, not doctors, run health care in this country. The only politician in Washington who is worried about health insurance may be George W. Bush. He will be out of a job and have to buy insurance for himself. He will be too young to qualify for Medicare.

Doctors and professional organisations are generally absent from policy discussions, preferring, I suppose, to wait until the election to start lobbying the next Congress. Having opposed the establishment of Medicare only to see their incomes soar over the next 40 years, primarily because of Medicare, physicians now mostly complain about the low levels of reimbursement from Medicare, not whether it should exist. And absolutely no one except state government is attending to the reality of a physician workforce badly aligned both by specialty and distribution, much less consider what will happen when 47 million more citizens start using the system.

The political primary season has been far more interesting than any of us had any right to expect. Normally over by February with a lull prior to the summer National Political Conventions, the Obama-Clinton fight has turned into a marathon that will likely go on almost to the summer. The possibility for real health policy discussions is being buried in the trench warfare of paid political operatives and media pundits.

People are losing jobs, homes, and health care and are increasingly desperate. Surveying their prospects, they see a country pouring its economic and moral wellbeing into a war and a mortgage Ponzi scheme, which will rescue the banks but not their families. Whether the national dysphoria about direction and hope translates into the political will to finally beat back the agents of the politics that led to this mess is still open to question. Gusty winds do, indeed, exist and they are rattling the doors of every house in the US. But I am not convinced that they will blow down the right buildings.

\section{John Frey}

DOI: 10.3399/bjgp08X302826 